
\title{
28 Research Suare \\ Spatial Effects of Internal and External Conflicts on Regional Maternal Mortality
}

\section{Mohsen Khezri}

Bu Ali Sina University Faculty of Economics and Social Science

Somayeh Razzaghi ( $\nabla$ s.razzaghi@basu.ac.ir)

Bu Ali Sina University Faculty of Economics and Social Science https://orcid.org/0000-0001-96545643

\section{Somayeh Khezri}

Urmia University

\section{Research}

Keywords: War, Foreign Pressure, Terrorism, Spatial Models, Health Service Expansion

Posted Date: March 15th, 2021

DOI: https://doi.org/10.21203/rs.3.rs-266280/v1

License: (c) (i) This work is licensed under a Creative Commons Attribution 4.0 International License. Read Full License 


\title{
Spatial Effects of Internal and External Conflicts on Regional Maternal Mortality
}

\author{
Mohsen Khezri \\ Assistant Professor of Economics, Faculty of Economics and Social Sciences, Bu-Ali Sina University, Hamedan, \\ Iran. E-mail: m.khezri@basu.ac.ir

\section{Somayeh Razzaghi} \\ Corresponding author: Assistant Professor of Economics, Faculty of Economics and Social Sciences, Bu-Ali Sina \\ University, Hamedan, Iran. E-mail: $\underline{\text { s.razzaghi@basu.ac.ir }}$
}

\section{Somayeh Khezri}

M.Sc. in economics. Urmia University. Somayeh.khezri1363@gmail.com 


\title{
Spatial Effects of Internal and External Conflicts on Regional Maternal Mortality
}

\begin{abstract}
Background: The high maternal mortality rates in African and Middle Eastern countries motivated the present study to explore the causes of such a phenomenon from a broader perspective. Extensive internal and external conflicts, including war and cross-border, foreign pressures, civil war, terrorism, and civil disorder conflicts, are the dominant feature of these countries. Therefore, this paper aims to elicit the influential factors in maternal mortality in the Middle East and Africa, with a special emphasis on the contribution of internal and external conflicts.

Methods: This study investigates data from 46 Asian and African countries from 2011 to 2017 on the regional effects of such conflicts on maternal mortality using spatial models.

Results: According to the results, the model control variables, except for trade openness, were found to have significant effects on the maternal mortality rate. Economic growth and natural resource rents through the expansion of health services showed significant effects on mortality reduction. In addition, the expansion of urbanization has led to an increase in maternal mortality rates. Also, most internal and external conflicts lead to a decrease in the production orientation towards health services, increasing maternal mortality rates, while war and cross-border have quite opposite effects.
\end{abstract}

Conclusions: The expansion of health services during the emergence of such conflicts reduces the maternal mortality rate. According to the results, conflicts such as war, foreign pressures, and terrorism in neighboring countries lead to increased mortality rates in the country of origin, suggesting that regional conflicts can have spillover effects on the regional extensions of maternal mortality rates. 


\section{Background}

Many factors could affect population health status rather than the health system, such as socioeconomic factors, gender inequality, natural disasters, and political unrest (e.g. warfare). Researchers profess that warfare has deeper and longer-lasting adverse effects on population health status than natural catastrophes (Swatzyna and Pillai,2013). Death, diseases, famine, malnutrition, and the destruction of health infrastructures are the unpleasant effects of warfare. Research has shown that females are more vulnerable than males to war, and women are at a larger risk of death due to the indirect effects of conflicts and poor health conditions in the postwar period (Li and Wen, 2005; Plumper and Neumayer, 2006; Urdal and Chi, 2013). Obermeyer et al (2008) demonstrated that women accounted for over 80 percent of reported war casualties. Internal and external conflicts restrict maternal health and significantly harm the well-being of mothers by shrinking the availability of public and private health care services. In $2008,50 \%$ of women who died in childbirth worldwide were originally from only eight countries with ongoing or recent armed conflicts (Hogan et al, 2010). In addition, O'Hare and Southall's (2007) research in Africa showed that maternal mortality ratios in war-torn countries were $45 \%$ higher than in non-conflict countries. In fact, according to the world health organization (WHO), $75 \%$ of countries observing a high maternal mortality rate in the world are war-affected.

Indeed, warfare is a key contributor to maternal mortality; however, conflicts have increased rapidly in the last decade, especially in the Middle East and Africa. These countries are mainly suffering from political instability and armed, ethnic, or religious conflicts; thus, they are among the worst countries across the world, with high maternal mortality rates. According to the WHO (2017), while the US recorded 19 deaths per 100000 live births, countries that had fragile situations and were conflict-affected recorded 568-fold deaths per 100000 births on average. This implies that women in war-affected countries are at nearly 29-fold risk of death during parturition as compared to American mothers. This situation is more serious in Sought Sudan, with the highest rate of maternal mortality (1150 deaths per 100000 live births). Chad stood at 1140 deaths, and Sierra Leone recorded 1120 deaths per 100000 live births. As these countries are experiencing high maternal mortality rates, they have implemented plans to reduce the maternal mortality rate to below 70 deaths per live birth by 2030; however, the dilemma of high maternal mortality in Africa remains a debacle.

Therefore, this paper aims to elicit the influential factors in maternal mortality in the Middle East and Africa, with a special emphasis on the contribution of internal and external conflicts (the most common features of Middle Eastern and African countries). Also, this paper applies a spatial econometric model to incorporate the spatial effects of internal and external conflicts in the Middle East and Africa since most researchers hold that the destructive effects of war permeate to neighboring countries. In fact, the existence of a strong economic, political, cultural, religious, and linguistic coherence among these countries leads to the expansion of such adverse events in a single country into a contagious process penetrating the neighboring countries. The transmission mechanism of the 2011 Arab Spring is an obvious example of the spatial effects of events in the region (Boserup et al., 2017). Therefore, the prominent distinction of the present study is the consideration of the spatial features of the maternal mortality rate in the region.

The remainder of the paper is organized as follows: Section 2 reviews the literature; Section 3 discusses the methodology of spatial econometrics; Section 4 reports the findings; and Section 5 concludes the paper. 


\section{Literature Review}

Although health services have a major impact on the maternal mortality rate, some other factors contribute to maternal mortality, such as war and internal and external conflicts, which could significantly harm women's well-being (Ruiz Chantero et al. (2019)). Warfare has adverse economic, social, political, and environmental consequences, resulting in poor health status in war-torn countries (Iqbal, 2006). Conflicts do not have the same effects on maternal mortality in different countries, and the scale of affection depends on health infrastructures in the pre-war period and governmental policies and priorities; however, channels through which warfare could affect maternal mortality are common in affected countries.

Conflicts impose effects on maternal health through different channels, including undernourishment, famines, food shortages, which are the consequences of the eradication of croplands through warfare and put women in danger during pregnancies and after childbirth (Gizelis and Cao, 2016). The deflection of healthcare budget to military expenditures, destroyed health infrastructures, the shortage of skilled health professionals, and the rebate of medical staff would suspend the obstetrical and maternal care in the long run and increase the risk of perilous miscarriage and pregnancy ending. Also, impoverishment, misery, and early marriage are the consequences of warfare, which stimulates maternal mortality (Kottegoda et al., 2008). In addition, in most conflicts, the parties of war cut off all resources, block the ways of delivering health care and medical equipment to war-torn regions, and ban the mobility of emergency vehicles; the pregnant mothers could hardly have access to maternity care (Mullany et al.,2008; Chandrasekhar et al., 2011).

Refugee crises are another channel through which conflicts increase the maternal mortality rate due to the absence of emergency obstetric care, a large risk of infectious diseases spreading among pregnant, and higher malnutrition levels during pregnancies and after birth due to family economic crises in refugee shelters (Urdal and Che, 2014). The hygienic condition is poor in refugee camps, and the refugees struggle with weak a recycling and sanitation system, overcrowding, and a lack of access to clean water and food in camps. Refugee crises in the Middle East and Africa are an important issue (Morillas et al., 2016). For example, the civil war in Burundi led to 300000 deaths and a flow of millions of displaced people to the neighboring countries, e.g., Tanzania and the Democratic Republic of Congo. In northern Uganda, two million people have been displaced internally. According to UNHCR (2017), Libya witnessed 226,000 internally displaced people, and there were 42,000 refugees. Also, 300,000 Palestinian refugees attempted to reside in Lebanon, and five million Syrians have been sheltered in the neighboring countries (such as Lebanon, Turkey, and Jordan). Refugees impose significant pressure on the host nations in order to meet their essential needs. Toole (2000) reported that the maternal mortality rates in refugee camps were 100 times higher than the normal mortality rate. This is more critical to pregnant women who live outside camps and have no access to public health services or international aid. The adverse impacts of war on maternal mortality are not limited to war-affected countries; it has also spill-over effects on maternal health indicators in the neighboring/host countries.

There is a bulk of studies investigating the adverse health effects of war ${ }^{1}$. A small number of works in the literature covered the relationship between maternal mortality and conflicts. Mirzazadah et al. (2020) investigated the impacts of conflicts on maternal mortality in

${ }^{1}$ For example. life expectancy by Plumper and Neumayer (2006) and Iqbal (2010), fertility rate by Randall (2005), Woldemicael (2008), and Iqbal (2010), prevalence of contagious diseases by Gustafson et al., (2001), disabilityadjusted life years by Ghobarah et al., (2003; 2004), infant mortality by Lindskog (2016) and Wigley (2017), maternal and child health by Abdul Cader and Perera (2011) and Welander et al, (2015), and gender gap in life expectancy by Plumper and Neumayer (2010). 
Afghanistan and compared various provinces based on the severity of the conflict through the Delphi process. They demonstrated that maternal health indicators were significantly lower in severe conflict provinces as compared to limit conflict provinces. They also mentioned that unfavorable economic and cultural conditions exacerbated the maternal mortality rate in waraffected provinces. Kotsadam and Ostby (2019) employed the sisterhood method to investigate the effect of armed conflicts on the maternal mortality rates in thirty countries within SubSaharan Africa from 1989 to 2013. They reported that local conflicts increased the risk of maternal mortality, and this risk was different in rural areas from that in rich and more educated areas. Wagner et al. (2019) analyzed the population effects of armed conflicts on non-combatant vulnerable populations, especially on pregnant women's ages (15-49 years) and orphanhood among children younger than 15 years of age in thirty-five African countries. They found that armed conflicts increased the risk of maternal deaths in Africa. Namasivayam (2017) explored the effects of armed conflicts on the utilization of maternal health services in Uganda. They concluded that the utilization of contraception and institutional deliveries among women was significantly lower in northern Uganda as a conflict-affected region than in the rest of the country. Urdal and Che (2013) examined the impacts of armed conflicts on fertility and maternal mortality across the world during 1970-2005. They concluded that the relationship between conflicts and the fertility rate was more significant in low-income countries, and that the maternal mortality rates were very large in conflict-affected countries.

The review of the literature indicated that the spatial feature of health problems that arise from the war in neighboring countries have been ignored in previous works. Thus, this paper seeks to fill this gap by applying spatial economic tools.

\section{Methods}

\section{Quantitative methods}

The present paper proposes an experimental model considering the socio-economic and political explanatory variables of maternal mortality in the Middle East and Africa in line with Wang (2014) and Zolala et al. (2012). According to Model (1), the logarithm of the maternal mortality

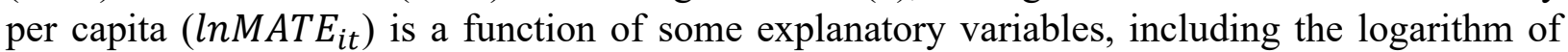
GDP per capita $(\ln G D P P)$, trade openness $(\ln O P E)$, natural resources rents $(\ln R E N T)$, urbanization $(\ln U R B)$, and national conflicts (such as internal and external conflicts $(\ln C O N)$ ). The linear form of Equation (1) is used for experimental estimation:

$$
\begin{aligned}
& \operatorname{lnMATE} E_{i t}=\beta_{1}+\beta_{2} \operatorname{lnGDP} P_{i t}+\beta_{3} \operatorname{lnOPE_{it}}+\beta_{4} \ln R E N T_{i t}+\beta_{5} \ln U R B_{i t}+\beta_{6} \operatorname{lnCON} \mathrm{N}_{i t}+ \\
& c_{i}(\text { optional })+\alpha_{t}(\text { optional })+v_{i t}
\end{aligned}
$$

A few variables, such as urbanization, energy consumption, and trade openness, are generally used as explanatory variables in the literature on maternal mortality rate (Zolala, 2012; Ensor et al. 2012; Wang, 2014; Bayati et al., 2016). Previous works stated that the share of health budget could extend when GDP has risen and economic development has happened in the region; therefore, the country could experience more trained health staff, provide more desirable primary health care, improve pregnant mothers' skills and knowledge to help reduce the maternal mortality rate. Urbanization is an important indicator of maternal mortality since it could improve infrastructures such as drinking water delivery, strong disposal system, further hospitals, urgent vehicles. It could also improve women's education and training and provide strong maternal care, which could decrease the maternal mortality rate in urban areas. The effect of natural resource rents on the maternal mortality rate is vague. In some cases, natural resourceendowed countries could efficiently allocate resource rents to health expenditure and educate 
people. This would help decrease maternal mortality; otherwise, the resource rent converts into a curse of resource (Nikzadian et al., 2019).

The spillover effects of higher internal and external conflicts on maternal mortality can be positive or negative, depending on the impacts of internal and external conflict on the financial resources allocated to health services. Thus, in order to operate these different aspects of effectiveness, the interaction terms of conflicts and GDP per capita are incorporated in a new form as:

$\operatorname{lnMATE} E_{i t}=\beta_{1}+\beta_{2} \ln G D P_{i t}+\beta_{3} \operatorname{lnOPE_{it}}+\beta_{4} \ln R E N T_{i t}+\beta_{5} \ln U R B_{i t}+\beta_{6} \ln C O N_{i t}+$ $\beta_{7}\left(\ln G D P_{i t} \times \operatorname{lnCON} N_{i t}\right)+c_{i}($ optional $)+\alpha_{t}($ optional $)+v_{i t}$

where $\left(\ln G D P_{i t} \times \ln C O N_{i t}\right)$ denotes the interaction term, while the coefficient of $\left(\ln G D P_{i t} \times\right.$ $\left.\ln C O N_{i t}\right)$ represents the interaction between the national conflict and GDP per capita. The effect of GDP per capita on maternal mortality is formulated as:

$\frac{d\left(\ln M A T E_{i t}\right)}{d\left(\ln G D P_{i t}\right)}=\beta_{2}+\beta_{7} \ln C O N_{i t}$

where $\beta_{7}$ is a positive coefficient. A higher level of conflicts implies a lower negative effect of GDP per capita on the maternal mortality rate, suggesting that the uncertainty arising from different types of conflicts leads to lower governmental financial resources allocated to the healthcare system, and vice versa.

The present study explores the impacts of material mortality factors and emphasizes the indicators of both internal and external conflicts in order to shed light on the spatial relationships between observations. To this end, several spatial models were incorporated. Anselin et al. (2008) argued that a spatial panel model could incorporate a lagged dependent parameter or apply a spatial autoregressive procedure into the error term. Furthermore, the spatial Durbin model was proposed by LeSage and Pace (2009). The spatial Durbin model involves variables with spatial lagging and model independence. The mathematical formulations of the spatial lag, spatial error, and spatial Durbin models are represented as:

$y_{i t}=\lambda \sum_{j=1}^{N} w_{i j} y_{j t}+\varphi+x_{i t} \beta+c_{i}($ optional $)+\alpha_{t}($ optional $)+v_{i t}$

$y_{i t}=\lambda \sum_{j=1}^{N} w_{i j} y_{j t}+\varphi+x_{i t} \beta+c_{i}($ optional $)+\alpha_{t}($ optional $)+u_{i t}$

$y_{i t}=\lambda \sum_{j=1}^{N} w_{i j} y_{j t}+\varphi+x_{i t} \beta+\sum_{j=1}^{N} w_{i j} x_{i j t} \theta+c_{i}($ optional $)+\alpha_{t}($ optional $)+v_{i t}$

in which $y_{i t}$ denotes a dependent variable for cross-sectional unit $i(i=1,2, \ldots N)$ at time $t(t=$ $1,2, \ldots, T) . x_{i t}$ represents the $1 \times \mathrm{K}$ exogenous variable vector, $\beta$ stands for a $K \times 1$ parameter vector, $\sum_{j=1}^{N} w_{i j} y_{j t}$ accounts for the interaction effect of dependent variable $y_{j t}$ in the neighboring units on the dependent variable, $w_{i j}$ denotes element $i, j$ of the pre-defined nonnegative $N \times N$ matrix of spatial weights, $\lambda$ stands for the responses of the endogenous interaction effects, $v_{i t}$ represents the error term with independent and identical distribution, $c_{i}$ is a spatial specific effect, and $\alpha_{t}$ represents a time-period specific effect.

\section{Data collection}

The data of forty-six countries in Africa and the Middle East from 2001 to 2017 were accumulated to investigate the effects of maternal mortality determinants. The data of other countries were excluded due to unavailability. Figure 1 represents a comparative observation for maternal mortality per capita in the countries under study. It illuminates the spatial interactions between different countries and the regional integration in maternal mortality. However, it is 
required to provide test statistics to accurately demonstrate the spatial effects. Moran's I is shown in Figure 2 as a common index.

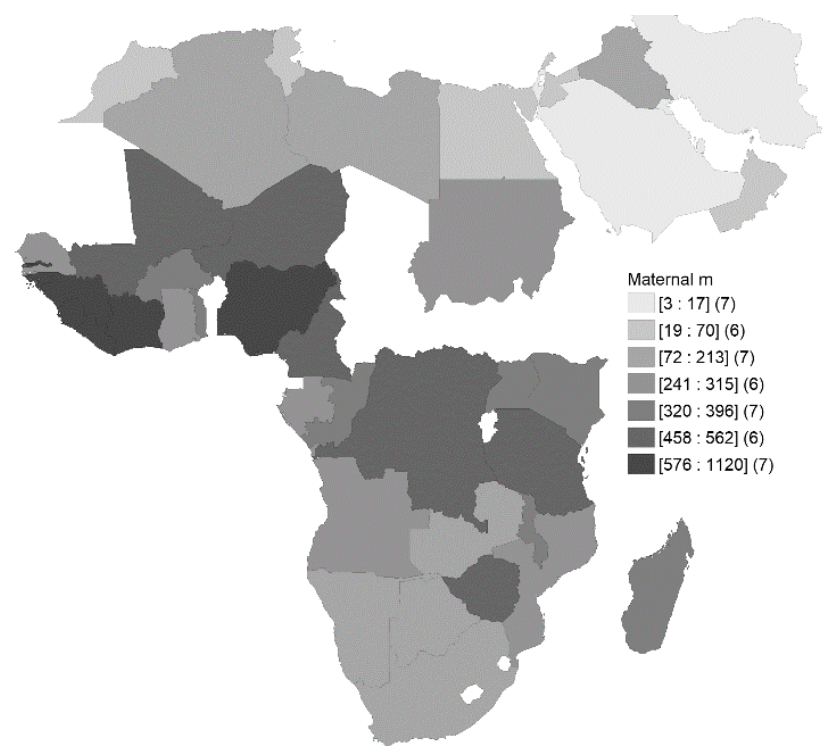

Figure 1. maternal mortality per capita

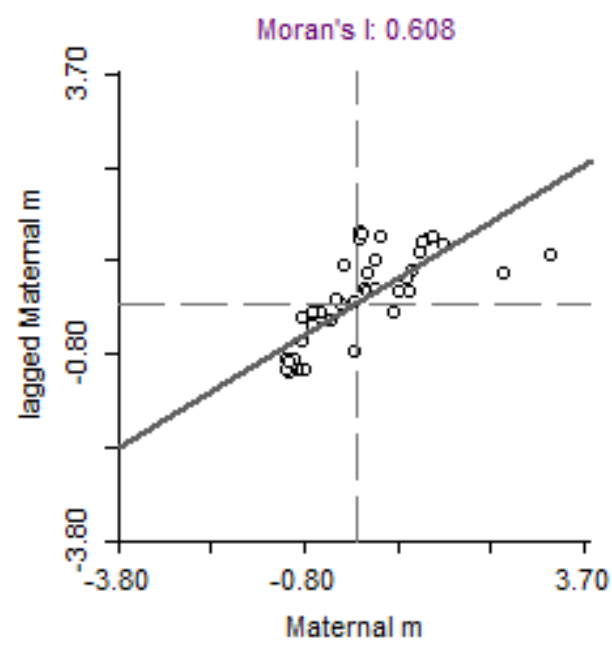

Figure 2. Moran's I statistics across countries

The regional observations and their spatial lag data are the dimensions of Figure 2. A positive Moran's I represents the spatial accumulation of similar values around the region, which is presented in Quadrants I and III, while a negative value represents the spatial accumulation of non-similar values that are presented in Quadrants II and IV. Most countries exhibit a positive autocorrelation; as can be inferred from the fitting lines, the positive autocorrelation is dominant. Moran's I statistics indicate that the neighboring countries have more similar maternal mortality rates. Therefore, spatial econometric models are employed to examine the effects of maternal mortality determinants. 


\section{Data analysis}

A summary of the constructed variables used in the analysis is presented in Table 1. Also, Table 2 reports the summarized statistics. All variables are presented in the logarithmic form; therefore, the estimated coefficients are elasticity.

Table 1. Variables constructed

\begin{tabular}{|c|c|c|}
\hline Variable & Variable constructed & Source \\
\hline $\ln M A T E_{i t}$ & 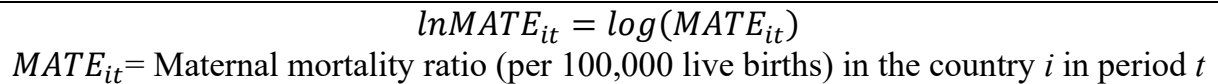 & WDI \\
\hline $\ln G D P_{i t}$ & $\begin{array}{c}\ln G D P P_{i t}=\log \left(G D P P_{i t}\right) \\
G D P_{i t}=\text { GDP per capita in } 2010 \text { prices } \$\end{array}$ & WDI \\
\hline $\ln O P E_{i t}$ & 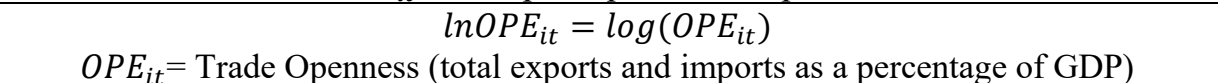 & WDI \\
\hline $\ln R E N T_{i t}$ & $\begin{array}{c}\ln R E N T_{i t}=\log \left(R E N T_{i t}\right) \\
R E N T_{i t}=\text { Total natural resources rents (as a percentage of GDP) }\end{array}$ & WDI \\
\hline $\ln U R B_{i t}$ & $\begin{array}{c}\ln U R B_{i t}=\log \left(U R B_{i t}\right) \\
U R B_{i t}=\text { Urban population (as a percentage of the total population) }\end{array}$ & WDI \\
\hline $\ln W A I_{i t}$ & $\begin{array}{c}\ln W A I_{i t}=\log \left(1+10 \times W A I_{i t}\right) \\
W A I_{i t}=\text { War Index }\end{array}$ & PRS \\
\hline $\ln C C I_{i t}$ & $\begin{array}{c}\ln C C I_{i t}=\log \left(1+10 \times C B I_{i t}\right) \\
C C I_{i t}=\text { Cross-Border Conflict Index }\end{array}$ & PRS \\
\hline $\ln F P I_{i t}$ & $\begin{array}{l}\ln F P I_{i t}=\log \left(1+10 \times F P I_{i t}\right) \\
F P I_{i t}=\text { Foreign Pressures Index }\end{array}$ & PRS \\
\hline $\operatorname{lnCWI} I_{i t}$ & $\begin{array}{c}\ln C W I_{i t}=\log \left(1+10 \times C W I_{i t}\right) \\
C W I_{i t}=\text { Civil War Index }\end{array}$ & PRS \\
\hline $\ln T E I_{i t}$ & $\begin{array}{c}\ln T E I_{i t}=\log \left(1+10 \times T E I_{i t}\right) \\
T E I_{i t}=\text { Terrorism Index }\end{array}$ & PRS \\
\hline $\ln C D I_{i t}$ & $\begin{array}{c}\ln C D I_{i t}=\log \left(1+10 \times C D I_{i t}\right) \\
C D I_{i t}=\text { Civil Disorder Index }\end{array}$ & PRS \\
\hline
\end{tabular}

WDI: World Development Indicator; https://datacatalog.worldbank.org/dataset/world-development-indicators. PRS: Political Risk Services International Country Risk Guide; www.prsgroup.com

Table 2. Summary of statistics during 2001-2017

\begin{tabular}{|c|c|c|c|c|c|c|c|c|c|c|c|}
\hline & lnMate $_{i t}$ & $\ln G D P_{i t}$ & $\operatorname{lnOPE_{it}}$ & $\ln R E N T_{i t}$ & $\overline{l n U R B_{i t}}$ & $\ln W A I_{i t}$ & $\ln C C I_{i t}$ & $\operatorname{lnFPI} I_{i t}$ & $\operatorname{lnCWI} I_{i t}$ & $\ln T E I_{i t}$ & $\ln C D I_{i t}$ \\
\hline Mean & 5.21 & 7.77 & 4.26 & 6.60 & 3.88 & 3.65 & 3.43 & 3.30 & 3.52 & 3.23 & 3.24 \\
\hline Media & & & & & & & & & & & \\
\hline $\mathrm{n}$ & 5.88 & 7.49 & 4.25 & 6.96 & 3.89 & 3.71 & 3.43 & 3.43 & 3.58 & 3.26 & 3.26 \\
\hline Max & 7.72 & 11.15 & 5.79 & 8.84 & 4.61 & 3.71 & 3.71 & 3.71 & 3.71 & 3.71 & 3.71 \\
\hline Min & 1.10 & 5.61 & 2.95 & 0.00 & 2.69 & 2.77 & 0.00 & 0.00 & 0.00 & 0.00 & 1.92 \\
\hline Std.D & 1.54 & 1.40 & 0.46 & 1.88 & 0.48 & 0.12 & 0.30 & 0.44 & 0.29 & 0.36 & 0.21 \\
\hline Obs & 782 & 782 & 782 & 782 & 782 & 782 & 782 & 782 & 782 & 782 & 782 \\
\hline
\end{tabular}

\section{Results}

In order to investigate the probability of the time-period fixed effects and spatial fixed effects in the model, two separate likelihood ratio (LR) tests were used. For this purpose, the model with simultaneous spatial and time-period fixed effects is compared to the model of time-period fixed effects and/or the model of spatial fixed effects. If the null hypothesis is rejected, the model with simultaneous spatial and time-period fixed effects is selected. On the other hand, if the null hypothesis is accepted, the subsequent model is selected. LR test statistics for the models are presented in Table 1. The test results indicate the significance of the LR test statistics and the rejection of the null hypothesis for only the time-period fixed effects in most models. Therefore, the spatial fixed effects are selected as the best model to proceed with estimation. 
Another test in Table 1 is used to examine whether the inclusion of the spatial lag or spatial error in the model in the absence of spatial interaction effects would lead to a significant improvement in the model. Thus, using the residuals of a non-spatial model, LM tests are applied to a spatially-lagged dependent variable and spatial error autoregressive (Elhorst, 2010a). The test statistic has the chi-square distribution. If the null hypothesis of the LM test is rejected, the presence of the spatial lagged model and the spatial error model is confirmed. Since the LR test results confirmed the existence of the spatial fixed effects, this study examines only the Lagrange Multiplier (LM) statistics for this model.

The results represented in Table 1 suggest that the test statistic values in all models are significant at the level of one percent. Therefore, spatial lagged and spatial error effects must be considered in the $\mathrm{CO}_{2}$ emission model. Hence, the presence of spatial interaction effects in the model emphasizes the need to consider such effects when investigating the factors affecting maternal mortality in experimental studies.

Table 3. Spatial lag or the spatial error in the spatial and time-period fixed-effect model

\begin{tabular}{|c|c|c|c|c|c|c|c|c|c|}
\hline & & \multicolumn{2}{|c|}{ Pooled OLS } & \multicolumn{2}{|c|}{ Spatial fixed effects } & \multicolumn{2}{|c|}{$\begin{array}{c}\text { Time-period fixed } \\
\text { effects }\end{array}$} & \multicolumn{2}{|c|}{$\begin{array}{l}\text { Spatial and time- } \\
\text { period fixed effects }\end{array}$} \\
\hline \multirow{3}{*}{$\begin{array}{c}\text { Model } \\
1\end{array}$} & $\begin{array}{c}\text { LM spatial } \\
\text { lag }\end{array}$ & 505.04 & $(0.000 * * *)$ & 510.981 & $(0.000 * * *)$ & 436.341 & $(0.000 * * *)$ & 14.181 & $(0.000 * * *)$ \\
\hline & $\begin{array}{l}\text { LM spatial } \\
\text { error }\end{array}$ & 426.882 & $(0.000 * * *)$ & 134.905 & $\left(0.000^{* * *}\right)$ & 245.647 & $(0.000 * * *)$ & 23.029 & $(0.000 * * *)$ \\
\hline & LR-test & & & 850.359 & $(0.000 * * *)$ & 2579.152 & $\left(0.000^{* * *}\right)$ & & \\
\hline \multirow{3}{*}{$\begin{array}{l}\text { Model } \\
2\end{array}$} & $\begin{array}{c}\text { LM spatial } \\
\text { lag }\end{array}$ & 478.95 & $(0.000 * * *)$ & 514.32 & $(0.000 * * *)$ & 402.464 & $(0.000 * * *)$ & 14.229 & $\left(0.000^{* * *}\right)$ \\
\hline & $\begin{array}{c}\text { LM spatial } \\
\text { error }\end{array}$ & 433.262 & $(0.000 * * *)$ & 133.092 & $(0.000 * * *)$ & 231.314 & $(0.000 * * *)$ & 23.101 & $(0.000 * * *)$ \\
\hline & LR-test & & & 850.349 & $(0.000 * * *)$ & 2534.489 & $(0.000 * * *)$ & & \\
\hline \multirow{3}{*}{$\begin{array}{l}\text { Model } \\
3\end{array}$} & $\begin{array}{c}\text { LM spatial } \\
\text { lag }\end{array}$ & 502.697 & $(0.000 * * *)$ & 512.897 & $(0.000 * * *)$ & 428.318 & $(0.000 * * *)$ & 13.583 & $(0.000 * * *)$ \\
\hline & $\begin{array}{c}\text { LM spatial } \\
\text { error }\end{array}$ & 423.204 & $(0.000 * * *)$ & 134.733 & $(0.000 * * *)$ & 235.993 & $(0.000 * * *)$ & 20.127 & $(0.000 * * *)$ \\
\hline & LR-test & & & 864.17 & $(0.000 * * *)$ & 2588.031 & $(0.000 * * *)$ & & \\
\hline \multirow{3}{*}{$\begin{array}{l}\text { Model } \\
4\end{array}$} & $\begin{array}{c}\text { LM spatial } \\
\text { lag }\end{array}$ & 491.327 & $(0.000 * * *)$ & 505.57 & $(0.000 * * *)$ & 413.436 & $(0.000 * * *)$ & 12.505 & $(0.000 * * *)$ \\
\hline & $\begin{array}{c}\text { LM spatial } \\
\text { error }\end{array}$ & 413.805 & $(0.000 * * *)$ & 127.38 & $(0.000 * * *)$ & 222.655 & $(0.000 * * *)$ & 18.648 & $(0.000 * * *)$ \\
\hline & LR-test & & & 855.947 & $(0.000 * * *)$ & 2571.463 & $(0.000 * * *)$ & & \\
\hline \multirow{3}{*}{$\begin{array}{l}\text { Model } \\
5\end{array}$} & $\begin{array}{c}\text { LM spatial } \\
\text { lag } \\
\end{array}$ & 519.168 & $(0.000 * * *)$ & 511.812 & $(0.000 * * *)$ & 448.245 & $(0.000 * * *)$ & 13.72 & $(0.000 * * *)$ \\
\hline & $\begin{array}{c}\text { LM spatial } \\
\text { error }\end{array}$ & $425.40 \mathrm{C}$ & $(0.000 * * *)$ & 133.778 & $(0.000 * * *)$ & 244.191 & $(0.000 * * *)$ & 21.89 & $(0.000 * * *)$ \\
\hline & LR-test & & & 849.71 & $\left(0.000^{* * *}\right)$ & 2580.347 & $(0.000 * * *)$ & & \\
\hline \multirow{3}{*}{$\begin{array}{l}\text { Model } \\
6\end{array}$} & $\begin{array}{c}\text { LM spatial } \\
\text { lag } \\
\end{array}$ & $466.18 \mathrm{~S}$ & $(0.000 * * *)$ & 511.201 & $(0.000 * * *)$ & 394.267 & $(0.000 * * *)$ & 13.953 & $(0.000 * * *)$ \\
\hline & $\begin{array}{l}\text { LM spatial } \\
\text { error }\end{array}$ & 369.173 & $(0.000 * * *)$ & 133.594 & $(0.000 * * *)$ & 183.685 & $(0.000 * * *)$ & 22.636 & $(0.000 * * *)$ \\
\hline & LR-test & & & 848.461 & $\left(0.000^{* * *}\right)$ & 2544.418 & $(0.000 * * *)$ & & \\
\hline \multirow{3}{*}{$\begin{array}{l}\text { Model } \\
7\end{array}$} & $\begin{array}{c}\text { LM spatial } \\
\text { lag }\end{array}$ & 505.81 & $(0.000 * * *)$ & 481.06 & $(0.000 * * *)$ & 440.957 & $(0.000 * * *)$ & 12.184 & $(0.000 * * *)$ \\
\hline & $\begin{array}{c}\text { LM spatial } \\
\text { error }\end{array}$ & 428.952 & $(0.000 * * *)$ & 105.453 & $(0.000 * * *)$ & 248.925 & $(0.000 * * *)$ & 18.046 & $(0.000 * * *)$ \\
\hline & LR-test & & & 813.734 & $\left(0.000^{* * *}\right)$ & 2577.738 & $(0.000 * * *)$ & & \\
\hline \multirow{3}{*}{$\begin{array}{l}\text { Model } \\
8\end{array}$} & $\begin{array}{c}\text { LM spatial } \\
\text { lag }\end{array}$ & 470.9 & $(0.000 * * *)$ & 499.883 & $(0.000 * * *)$ & 402.605 & $(0.000 * * *)$ & 13.253 & $(0.000 * * *)$ \\
\hline & $\begin{array}{l}\text { LM spatial } \\
\text { error }\end{array}$ & 410.133 & $(0.000 * * *)$ & 111.062 & $(0.000 * * *)$ & 224.7 & $(0.000 * * *)$ & 20.895 & $(0.000 * * *)$ \\
\hline & LR-test & & & 826.121 & $(0.000 * * *)$ & 2549.348 & $(0.000 * * *)$ & & \\
\hline
\end{tabular}




\begin{tabular}{|c|c|c|c|c|c|c|c|c|c|}
\hline \multirow{3}{*}{$\begin{array}{c}\text { Model } \\
9\end{array}$} & $\begin{array}{c}\text { LM spatial } \\
\text { lag }\end{array}$ & 490.371 & $(0.000 * * *)$ & 506.781 & $(0.000 * * *)$ & 425.25 & $(0.000 * * *)$ & 13.343 & $(0.000 * * *)$ \\
\hline & $\begin{array}{l}\text { LM spatial } \\
\text { error }\end{array}$ & 391.695 & $\left(0.000^{* * *}\right)$ & 130.434 & $(0.000 * * *)$ & 223.661 & $\left(0.000^{* * *}\right)$ & 19.573 & $(0.000 * * *)$ \\
\hline & LR-test & & & 853.453 & $(0.000 * * *)$ & 2588.222 & $(0.000 * * *)$ & & \\
\hline \multirow{3}{*}{$\begin{array}{l}\text { Model } \\
10\end{array}$} & $\begin{array}{c}\text { LM spatial } \\
\text { lag }\end{array}$ & 491.745 & $(0.000 * * *)$ & 509.193 & $(0.000 * * *)$ & 418.404 & $(0.000 * * *)$ & 11.981 & $(0.001 * * *)$ \\
\hline & $\begin{array}{l}\text { LM spatial } \\
\text { error }\end{array}$ & 403.248 & $(0.000 * * *)$ & 129.037 & $(0.000 * * *)$ & 220.482 & $\left(0.000^{* * *}\right)$ & 17.775 & $\left(0.000^{* * *}\right)$ \\
\hline & LR-test & & & 857.485 & $(0.000 * * *)$ & 2574.464 & $(0.000 * * *)$ & & \\
\hline \multirow{3}{*}{$\begin{array}{c}\text { Model } \\
11\end{array}$} & $\begin{array}{c}\text { LM spatial } \\
\text { lag }\end{array}$ & 519.775 & $(0.000 * * *)$ & 475.895 & $(0.000 * * *)$ & 458.1 & $(0.000 * * *)$ & 13.493 & $(0.000 * * *)$ \\
\hline & $\begin{array}{l}\text { LM spatial } \\
\text { error }\end{array}$ & 419.215 & $(0.000 * * *)$ & 93.856 & $(0.000 * * *)$ & 252.215 & $(0.000 * * *)$ & 21.495 & $(0.000 * * *)$ \\
\hline & LR-test & & & 825.83 & $(0.000 * * *)$ & 2581.065 & $\left(0.000^{* * *}\right)$ & & \\
\hline \multirow{3}{*}{$\begin{array}{c}\text { Model } \\
12\end{array}$} & $\begin{array}{c}\text { LM spatial } \\
\text { lag }\end{array}$ & 469.207 & $(0.000 * * *)$ & 497.582 & $(0.000 * * *)$ & 402.466 & $(0.000 * * *)$ & 13.893 & $(0.000 * * *)$ \\
\hline & $\begin{array}{l}\text { LM spatial } \\
\text { error }\end{array}$ & 369.593 & $(0.000 * * *)$ & 116.908 & $(0.000 * * *)$ & 191.116 & $(0.000 * * *)$ & 22.477 & $(0.000 * * *)$ \\
\hline & LR-test & & & 836.458 & $(0.000 * * *)$ & 2544.17 & $(0.000 * * *)$ & & \\
\hline \multirow{3}{*}{$\begin{array}{c}\text { Model } \\
13\end{array}$} & $\begin{array}{c}\text { LM spatial } \\
\text { lag }\end{array}$ & 529.465 & $(0.000 * * *)$ & 436.868 & $(0.000 * * *)$ & 473.684 & $(0.000 * * *)$ & 12.188 & $(0.000 * * *)$ \\
\hline & $\begin{array}{l}\text { LM spatial } \\
\text { error }\end{array}$ & 470.308 & $(0.000 * * *)$ & 58.735 & $(0.000 * * *)$ & 291.87 & $(0.000 * * *)$ & 18.045 & $(0.000 * * *)$ \\
\hline & LR-test & & & 775.209 & $(0.000 * * *)$ & 2571.096 & $\left(0.000^{* * *}\right)$ & & \\
\hline
\end{tabular}

Note: $\mathrm{p}$-value, $* * *, * *$, and $*$ show significance at $1 \%, 5 \%$, and $10 \%$ level respectively

Source: Authors' estimations.

Table 2 represents the Hausman test results to examine the possibility of replacing the fixedeffect model with a random-effect model. The null hypothesis in this test emphasizes the existence of random effects in the model. The results of the Hausman test reject the assumption of random effects in the spatial lag model for all the models and confirm the existence of fixed effects at a significance level of $1 \%$.

Finally, this study evaluates two separate hypotheses $H_{0}: \theta=0$ and $H_{0}: \theta+\lambda \beta=0$ in Equation (3). If the first hypothesis is the case, the spatial Durbin model is simplified into the spatial lag model. On the other hand, if the second hypothesis is the case, the spatial Durbin model can be simplified into a spatial error model (Burridge, 1981). The present work uses the LR test or Wald test to explore whether the existence of the spatial lagged independent variable in the model is significant. Each of these two tests has positive and negative characteristics. LR tests are employed to estimate more models, while Wald tests are sensitive to nonlinear constraints.

The test results in Table 2 provide the same outcome for the fixed- and random-effect models. The statistical value of the two tests (i.e., the LR and the Wald test) is significant for all models, and the spatial Durbin model cannot be converted into the spatial error model and spatial lag model in any of the models. Therefore, the existence of the spatial lagged independent variable is also confirmed; finally, the spatial Durbin model is the basis for the analysis of the estimation results. 
Table 4. Spatial Durbin model and Hausman test results

\begin{tabular}{|c|c|c|c|c|c|c|}
\hline & \multicolumn{2}{|c|}{ Hausman test } & \multicolumn{2}{|c|}{ Wald test } & \multicolumn{2}{|c|}{ LR test } \\
\hline & $\begin{array}{l}\text { spatial } \\
\text { Durbin } \\
\text { model }\end{array}$ & $\begin{array}{l}\text { spatial lag } \\
\text { model }\end{array}$ & $\begin{array}{c}\text { spatial Durbin } \\
\text { model against } \\
\text { spatial lag model }\end{array}$ & $\begin{array}{c}\text { spatial Durbin } \\
\text { model against } \\
\text { spatial error model }\end{array}$ & $\begin{array}{c}\text { spatial Durbin } \\
\text { model against } \\
\text { spatial lag model }\end{array}$ & $\begin{array}{c}\text { spatial Durbin } \\
\text { model against } \\
\text { spatial error model }\end{array}$ \\
\hline \multirow{2}{*}{$\begin{array}{c}\text { Model } \\
1\end{array}$} & 26.244 & 15.27 & 38.992 & 41.117 & 46.641 & 48.5 \\
\hline & $(0.000 * * *)$ & $(0.084 *)$ & $(0.000 * * *)$ & $(0.000 * * *)$ & $(0.000 * * *)$ & $(0.000 * * *)$ \\
\hline \multirow{2}{*}{$\begin{array}{c}\text { Model } \\
2\end{array}$} & 30.655 & 20.026 & 49.153 & 50.013 & 58.116 & 60.456 \\
\hline & $(0.000 * * *)$ & $\left(0.045^{* *}\right)$ & $(0.000 * * *)$ & $(0.000 * * *)$ & $(0.000 * * *)$ & $(0.000 * * *)$ \\
\hline \multirow{2}{*}{$\begin{array}{l}\text { Model } \\
3\end{array}$} & 24.613 & 12.081 & 38.026 & 40.285 & 45.808 & 47.913 \\
\hline & $(0.000 * * *)$ & $(0.358)$ & $(0.000 * * *)$ & $(0.000 * * *)$ & $(0.000 * * *)$ & $\left(0.000^{* * *}\right)$ \\
\hline \multirow{2}{*}{$\begin{array}{c}\text { Model } \\
4\end{array}$} & 23.532 & 14.917 & 57.057 & 58.173 & 66.735 & 67.914 \\
\hline & $(0.001 * * *)$ & $(0.186)$ & $(0.000 * * *)$ & $\left(0.000^{* * *}\right)$ & $(0.000 * * *)$ & $\left(0.000^{* * *}\right)$ \\
\hline \multirow{2}{*}{$\begin{array}{c}\text { Model } \\
5 \\
\end{array}$} & 28.754 & 27.039 & 49.675 & 51.837 & 59.2 & 60.299 \\
\hline & $\left(0.000^{* * *}\right)$ & $(0.005 * * *)$ & $(0.000 * * *)$ & $\left(0.000^{* * *}\right)$ & $(0.000 * * *)$ & $(0.000 * * *)$ \\
\hline \multirow{2}{*}{$\begin{array}{c}\text { Model } \\
6 \\
\end{array}$} & 30.471 & 25.244 & 52.788 & 55.08 & 62.771 & 63.831 \\
\hline & $(0.000 * * *)$ & $(0.008 * * *)$ & $(0.000 * * *)$ & $\left(0.000^{* * *}\right)$ & $(0.000 * * *)$ & $\left(0.000^{* * *}\right)$ \\
\hline \multirow{2}{*}{$\begin{array}{c}\text { Model } \\
7 \\
\end{array}$} & 28.097 & 28.257 & 36.18 & 37.761 & 43.118 & 44.288 \\
\hline & $(0.000 * * *)$ & $(0.003 * * *)$ & $(0.000 * * *)$ & $\left(0.000^{* * *}\right)$ & $(0.000 * * *)$ & $(0.000 * * *)$ \\
\hline \multirow{2}{*}{$\begin{array}{c}\text { Model } \\
8 \\
\end{array}$} & 27.911 & 22.076 & 51.665 & 52.622 & 60.985 & 63.934 \\
\hline & $(0.000 * * *)$ & $(0.054 *)$ & $(0.000 * * *)$ & $(0.000 * * *)$ & $(0.000 * * *)$ & $(0.000 * * *)$ \\
\hline \multirow{2}{*}{$\begin{array}{c}\text { Model } \\
9 \\
\end{array}$} & 22.255 & 13.149 & 37.944 & 40.939 & 46.036 & 48.704 \\
\hline & $(0.002 * * *)$ & $(0.436)$ & $(0.000 * * *)$ & $(0.000 * * *)$ & $(0.000 * * *)$ & $(0.000 * * *)$ \\
\hline \multirow{2}{*}{$\begin{array}{c}\text { Model } \\
10 \\
\end{array}$} & 26.268 & 14.508 & 63.135 & 64.048 & 73.391 & 75.575 \\
\hline & $(0.000 * * *)$ & $(0.339)$ & $(0.000 * * *)$ & $(0.000 * * *)$ & $(0.000 * * *)$ & $(0.000 * * *)$ \\
\hline \multirow{2}{*}{$\begin{array}{c}\text { Model } \\
11 \\
\end{array}$} & 25.639 & 18.843 & 45.225 & 48.786 & 53.538 & 56.275 \\
\hline & $(0.001 * * *)$ & $(0.128)$ & $(0.000 * * *)$ & $(0.000 * * *)$ & $(0.000 * * *)$ & $(0.000 * * *)$ \\
\hline \multirow{2}{*}{$\begin{array}{c}\text { Model } \\
12 \\
\end{array}$} & 37.304 & 30.431 & 83.386 & 83.868 & 91.134 & 93.201 \\
\hline & $(0.000 * * *)$ & $(0.004 * * *)$ & $(0.000 * * *)$ & $(0.000 * * *)$ & $(0.000 * * *)$ & $(0.000 * * *)$ \\
\hline \multirow{2}{*}{$\begin{array}{c}\text { Model } \\
13\end{array}$} & 35.36 & 21.347 & 56.304 & 56.18 & 60.632 & 61.725 \\
\hline & $(0.000 * * *)$ & $\left(0.066^{*}\right)$ & $(0.000 * * *)$ & $(0.000 * * *)$ & $(0.000 * * *)$ & $(0.000 * * *)$ \\
\hline
\end{tabular}

Note: p-value, $* * *, * *$, and $*$ show significance at $1 \%, 5 \%$, and $10 \%$ level respectively

Source: Authors' estimations.

According to Table 5, an increase of $1 \%$ in the GDP per capita leads to a significant decrease of nearly $0.474 \%$ in the maternal mortality rate. However, trade openness does not show a significant effect. Also, the growth of natural resource rents in most models leads to a significant reduction in maternal mortality rates. Urbanization is one of the positive dimensions in the enhancement of maternal mortality rates in the countries under study. Among the conflict variables, a rise in war and cross-border conflicts would raise the maternal mortality rate, whereas the other variables yield a lower mortality rate. It should be noted that an increase in conflict indicators in the countries represents a reduction in such conflicts; the incident of war and cross-border conflicts leads to a reduction in maternal mortality rates, in contrast to theoretical implications. Accordingly, Table 6 examines the spillover effects of conflicts.

Table 5. Estimation results for Equation (1)

\begin{tabular}{cccccccc}
\hline & Model 1 & Model 2 & Model 3 & Model 4 & Model 5 & Model 6 & Model 7 \\
\hline $\ln G D P$ & -0.474 & -0.473 & -0.469 & -0.467 & -0.433 & -0.466 & -0.464 \\
& $\left(0.000^{* * *}\right)$ & $\left(0.000^{* * *}\right)$ & $\left(0.000^{* * *}\right)$ & $\left(0.000^{* * *}\right)$ & $\left(0.000^{* * *}\right)$ & $\left(0.000^{* * *}\right)$ & $\left(0.000^{* * *}\right)$ \\
$\ln O P E$ & 0.005 & -0.001 & 0.007 & -0.005 & 0.005 & 0.008 & 0.004 \\
& $(0.786)$ & $(0.977)$ & $(0.741)$ & $(0.788)$ & $(0.783)$ & $(0.689)$ & $(0.858)$ \\
$\ln R E N T$ & -0.022 & -0.014 & -0.02 & -0.017 & -0.021 & -0.02 & -0.021 \\
& $\left(0.018^{* *}\right)$ & $(0.124)$ & $\left(0.028^{* *}\right)$ & $\left(0.054^{*}\right)$ & $\left(0.016^{* *}\right)$ & $\left(0.027^{* *}\right)$ & $\left(0.019^{* *}\right)$ \\
$\ln U R B$ & 0.284 & 0.345 & 0.312 & 0.242 & 0.227 & 0.267 & 0.294 \\
& $\left(0.008^{* * *}\right)$ & $\left(0.001^{* * *}\right)$ & $\left(0.003^{* * *}\right)$ & $\left(0.023^{* *}\right)$ & $\left(0.029^{* *}\right)$ & $\left(0.011^{* *}\right)$ & $\left(0.006^{* * *}\right)$ \\
\hline
\end{tabular}




\begin{tabular}{|c|c|c|c|c|c|c|c|}
\hline $\ln W A R$ & & $\begin{array}{c}0.205 \\
(0.000 * * *)\end{array}$ & & & & & \\
\hline $\ln C C I$ & & & $\begin{array}{c}0.037 \\
(0.000 * * *)\end{array}$ & & & & \\
\hline $\ln F P I$ & & & & $\begin{array}{c}-0.036 \\
\left(0.000^{* * *}\right)\end{array}$ & & & \\
\hline $\ln C W I$ & & & & & $\begin{array}{c}-0.077 \\
(0.000 * * *)\end{array}$ & & \\
\hline $\ln T E I$ & & & & & & $\begin{array}{c}-0.037 \\
(0.000 * * *)\end{array}$ & \\
\hline $\ln C D I$ & & & & & & & $\begin{array}{c}-0.062 \\
(0.004 * * *)\end{array}$ \\
\hline$W \times \ln G D P$ & $\begin{array}{c}-0.212 \\
\left(0.044^{* *}\right)\end{array}$ & $\begin{array}{c}-0.199 \\
\left(0.056^{*}\right)\end{array}$ & $\begin{array}{c}-0.193 \\
(0.064 *)\end{array}$ & $\begin{array}{c}-0.283 \\
(0.007 * * *)\end{array}$ & $\begin{array}{c}-0.228 \\
(0.034 * *)\end{array}$ & $\begin{array}{c}-0.239 \\
(0.022 * *)\end{array}$ & $\begin{array}{c}-0.178 \\
\left(0.099^{*}\right)\end{array}$ \\
\hline$W \times \ln O P E$ & $\begin{array}{c}0.015 \\
(0.817)\end{array}$ & $\begin{array}{c}0.012 \\
(0.855)\end{array}$ & $\begin{array}{c}0.014 \\
(0.828)\end{array}$ & $\begin{array}{l}-0.051 \\
(0.427)\end{array}$ & $\begin{array}{c}0.041 \\
(0.514)\end{array}$ & $\begin{array}{c}0.04 \\
(0.535)\end{array}$ & $\begin{array}{c}0.031 \\
(0.635)\end{array}$ \\
\hline$W \times \ln R E N T$ & $\begin{array}{c}0.092 \\
(0.000 * * *)\end{array}$ & $\begin{array}{c}0.089 \\
(0.000 * * *)\end{array}$ & $\begin{array}{c}0.086 \\
(0.000 * * *)\end{array}$ & $\begin{array}{c}0.123 \\
(0.000 * * *)\end{array}$ & $\begin{array}{c}0.107 \\
(0.000 * * *)\end{array}$ & $\begin{array}{c}0.092 \\
\left(0.000^{* * *}\right)\end{array}$ & $\begin{array}{c}0.089 \\
(0.000 * * *)\end{array}$ \\
\hline$W \times \ln U R B$ & $\begin{array}{c}-0.75 \\
(0.000 * * *)\end{array}$ & $\begin{array}{c}-0.679 \\
(0.001 * * *)\end{array}$ & $\begin{array}{c}-0.773 \\
(0.000 * * *)\end{array}$ & $\begin{array}{c}-0.877 \\
\left(0.000^{* * *}\right)\end{array}$ & $\begin{array}{c}-0.755 \\
(0.000 * * *)\end{array}$ & $\begin{array}{c}-0.698 \\
(0.000 * * *)\end{array}$ & $\begin{array}{c}-0.718 \\
(0.000 * * *)\end{array}$ \\
\hline$W \times \ln W A R$ & & $\begin{array}{c}-0.472 \\
(0.008 * * *)\end{array}$ & & & & & \\
\hline$W \times \ln C C I$ & & & $\begin{array}{l}-0.017 \\
(0.618)\end{array}$ & & & & \\
\hline$W \times \ln F P I$ & & & & $\begin{array}{c}-0.092 \\
(0.000 * * *)\end{array}$ & & & \\
\hline$W \times \ln C W I$ & & & & & $\begin{array}{l}-0.051 \\
(0.174)\end{array}$ & & \\
\hline$W \times \ln T E I$ & & & & & & $\begin{array}{c}-0.085 \\
(0.000 * * *)\end{array}$ & \\
\hline$W \times \ln C D I$ & & & & & & & $\begin{array}{l}-0.034 \\
(0.544)\end{array}$ \\
\hline$W \times \ln M A T E$ & $\begin{array}{c}0.018 \\
(0.788)\end{array}$ & $\begin{array}{c}0.037 \\
(0.572)\end{array}$ & $\begin{array}{c}0.035 \\
(0.599)\end{array}$ & $\begin{array}{l}-0.074 \\
(0.287)\end{array}$ & $\begin{array}{l}-0.038 \\
(0.579)\end{array}$ & $\begin{array}{l}-0.06 \\
(0.39)\end{array}$ & $\begin{array}{c}0.003 \\
(0.969)\end{array}$ \\
\hline
\end{tabular}

Note: $\mathrm{p}$-value, $* * *, * *$, and $*$ show significance at $1 \%, 5 \%$, and $10 \%$ level respectively

Source: Authors' estimations.

Table 6 provides the estimation results of Equation (5). The incorporation of the spillover effects of internal and external conflicts on GDP per capita yielded the same and significant results for all types of conflicts. The non-inclusion of the interaction term seems to produce misleading results. Based on the results and Equation (6), the spillover effects are negative for some conflict variables and positive for some others:

$$
\begin{aligned}
& \frac{d\left(\ln M A T E_{i t}\right)}{d\left(\ln G D P_{i t}\right)}=-1.514+0.172 \times \ln W A R_{i t} \\
& \frac{d\left(\operatorname{lnMATE}_{i t}\right)}{d\left(\ln G D P_{i t}\right)}=-0.693+0.036 \times \ln C C I_{i t} \\
& \frac{d\left(\operatorname{lnMATE}_{i t}\right)}{d\left(\ln G D P_{i t}\right)}=-0.18-0.046 \times \ln F P I_{i t} \\
& \frac{d\left(\ln M A T E_{i t}\right)}{d\left(\operatorname{lnGDP} P_{i t}\right)}=-0.149-0.096 \times \ln C W I_{i t} \\
& \frac{d\left(\ln M A T E_{i t}\right)}{d\left(\ln G D P_{i t}\right)}=-0.226-0.042 \times \ln T E I_{i t} \\
& \frac{d\left(\ln M A T E_{i t}\right)}{d\left(\ln G D P_{i t}\right)}=-0.003-0.074 \times \ln C D I_{i t}
\end{aligned}
$$


Table 6. Estimation results for Equation (2)

\begin{tabular}{|c|c|c|c|c|c|c|}
\hline & Model 8 & Model 9 & Model 10 & Model 11 & Model 12 & Model 13 \\
\hline $\ln G D P$ & $\begin{array}{c}-1.514 \\
(0,000 * * *)\end{array}$ & $\begin{array}{c}-0.693 \\
(0.000 * * *)\end{array}$ & $\begin{array}{c}-0.18 \\
(0.017)\end{array}$ & $\begin{array}{c}0.149 \\
0183)\end{array}$ & $\begin{array}{l}-0.226 \\
(0.011)\end{array}$ & $\begin{array}{c}-0.003 \\
(0.981)\end{array}$ \\
\hline $\ln O P E$ & $\begin{array}{c}0.009 \\
(0.653)\end{array}$ & $\begin{array}{c}0.014 \\
(0.472)\end{array}$ & $\begin{array}{c}0.002 \\
(0.936)\end{array}$ & $\begin{array}{l}-0.007 \\
(0.709)\end{array}$ & $\begin{array}{c}0.002 \\
(0.904)\end{array}$ & $\begin{array}{c}0.005 \\
(0.809)\end{array}$ \\
\hline $\ln R E N T$ & $\begin{array}{l}-0.011 \\
(0.208)\end{array}$ & $\begin{array}{c}-0.021 \\
(0.02 * *)\end{array}$ & $\begin{array}{c}-0.016 \\
\left(0.069^{*}\right)\end{array}$ & $\begin{array}{l}-0.014 \\
(0.115)\end{array}$ & $\begin{array}{l}-0.014 \\
(0.126)\end{array}$ & $\begin{array}{c}-0.017 \\
\left(0.058^{*}\right)\end{array}$ \\
\hline $\ln U R B$ & $\begin{array}{c}0.307 \\
(0.003 * * *)\end{array}$ & $\begin{array}{c}0.29 \\
\left(0.006^{* * *}\right)\end{array}$ & $\begin{array}{c}0.311 \\
\left(0.003^{* * *}\right)\end{array}$ & $\begin{array}{c}0.299 \\
(0.003 * * *)\end{array}$ & $\begin{array}{c}0.322 \\
(0.002 * * *)\end{array}$ & $\begin{array}{c}0.249 \\
(0.017)\end{array}$ \\
\hline $\begin{array}{c}\ln W A R \\
\ln G D P \times \ln W A R\end{array}$ & $\begin{array}{c}-1.152 \\
(0.000 * * *) \\
0.172 \\
(0.000 * * *)\end{array}$ & & & & & \\
\hline $\begin{array}{c}\ln C C I \\
\ln G D P \times \ln C C I\end{array}$ & & $\begin{array}{c}-0.24 \\
(0.002 * * *) \\
0.036 \\
\left(0.000^{* * *}\right)\end{array}$ & & & & \\
\hline $\begin{array}{c}\ln F P I \\
\ln G D P \times \ln F P I\end{array}$ & & & $\begin{array}{c}0.328 \\
(0.000 * * *) \\
-0.046 \\
(0.000 * * *)\end{array}$ & & & \\
\hline $\begin{array}{c}\ln C W I \\
\ln G D P \times \ln C W I\end{array}$ & & & & $\begin{array}{c}0.636 \\
(0.000 * * *) \\
-0.096 \\
(0.000 * * *)\end{array}$ & & \\
\hline $\begin{array}{c}\ln T E I \\
\ln G D P \times \ln T E I\end{array}$ & & & & & $\begin{array}{c}0.299 \\
(0.01 * *) \\
-0.042 \\
(0.003 * * *)\end{array}$ & \\
\hline $\ln C D I$ & & & & & & $\begin{array}{c}0.5 \\
\left(0.000^{* * *}\right)\end{array}$ \\
\hline $\ln G D P \times \ln C D I$ & & & & & & $\begin{array}{c}-0.074 \\
(0.000 * * *)\end{array}$ \\
\hline$W \times \ln G D P$ & $\begin{array}{c}0.973 \\
(0.141)\end{array}$ & $\begin{array}{c}-0.092 \\
(0.705)\end{array}$ & $\begin{array}{c}-0.588 \\
(0.004 * * *)\end{array}$ & $\begin{array}{c}-0.749 \\
\left(0.057^{*}\right)\end{array}$ & $\begin{array}{c}-1.32 \\
\left(0.000^{* * *}\right)\end{array}$ & $\begin{array}{c}-1.386 \\
(0.000 * * *)\end{array}$ \\
\hline$W \times \ln O P E$ & $\begin{array}{c}0.009 \\
(0.886)\end{array}$ & $\begin{array}{c}0.006 \\
(0.922)\end{array}$ & $\begin{array}{l}-0.042 \\
(0.509)\end{array}$ & $\begin{array}{c}0.074 \\
(0.238)\end{array}$ & $\begin{array}{c}0.051 \\
(0.415)\end{array}$ & $\begin{array}{l}0.027 \\
(0.66)\end{array}$ \\
\hline$W \times \ln R E N T$ & $\begin{array}{c}0.084 \\
\left(0.000^{* * *}\right)\end{array}$ & $\begin{array}{c}0.088 \\
(0.000 * * *)\end{array}$ & $\begin{array}{c}0.119 \\
(0.000 * * *)\end{array}$ & $\begin{array}{c}0.089 \\
(0.000 * * *)\end{array}$ & $\begin{array}{c}0.063 \\
(0.007 * * *)\end{array}$ & $\begin{array}{c}0.062 \\
\left(0.009^{* * *}\right)\end{array}$ \\
\hline$W \times \ln U R B$ & $\begin{array}{c}-0.664 \\
(0.001 * * *)\end{array}$ & $\begin{array}{c}-0.704 \\
(0.000 * * *)\end{array}$ & $\begin{array}{c}-0.956 \\
\left(0.000^{* * *}\right)\end{array}$ & $\begin{array}{c}-0.747 \\
\left(0.000^{* * *}\right)\end{array}$ & $\begin{array}{c}-0.859 \\
(0.000 * * *)\end{array}$ & $\begin{array}{c}-0.832 \\
(0.000 * * *)\end{array}$ \\
\hline$W \times \ln W A R$ & $\begin{array}{c}1.072 \\
(0.198)\end{array}$ & & & & & \\
\hline$W \times \ln G D P \times \ln W A R$ & $\begin{array}{c}-0.189 \\
\left(0.069^{*}\right)\end{array}$ & & & & & \\
\hline$W \times \ln C C I$ & & $\begin{array}{c}0.142 \\
(0.535)\end{array}$ & & & & \\
\hline$W \times \ln G D P \times \ln C C I$ & & $\begin{array}{l}-0.021 \\
(0.478)\end{array}$ & & & & \\
\hline$W \times \ln F P I$ & & & $\begin{array}{c}-0.489 \\
\left(0.062^{*}\right)\end{array}$ & & & \\
\hline$W \times \ln G D P \times \ln F P I$ & & & $\begin{array}{c}0.052 \\
(0.122)\end{array}$ & & & \\
\hline$W \times \ln C W I$ & & & & $\begin{array}{l}-0.684 \\
(0.126)\end{array}$ & & \\
\hline$W \times \ln G D P \times \ln C W I$ & & & & $\begin{array}{c}0.085 \\
(0.159)\end{array}$ & & \\
\hline$W \times \ln T E I$ & & & & & -1.584 & \\
\hline
\end{tabular}




\begin{tabular}{|c|c|c|c|c|c|c|}
\hline$W \times \ln G D P \times \ln T E I$ & & & & & $\begin{array}{c}(0.000 * * *) \\
0.182 \\
(0.000 * * *)\end{array}$ & \\
\hline$W \times \ln C D I$ & & & & & & $\begin{array}{c}-1.404 \\
\left(0.000^{* * *}\right)\end{array}$ \\
\hline$W \times \ln G D P \times \ln C D I$ & & & & & & $\begin{array}{c}0.19 \\
\left(0.000^{* * *}\right)\end{array}$ \\
\hline$W \times \ln M A T E$ & $\begin{array}{c}0.069 \\
(0.291)\end{array}$ & $\begin{array}{c}0.036 \\
(0.589)\end{array}$ & $\begin{array}{c}-0.061 \\
(0.381)\end{array}$ & $\begin{array}{c}0.004 \\
(0.956)\end{array}$ & $\begin{array}{l}-0.125 \\
(0.078)\end{array}$ & $\begin{array}{c}0.002 \\
(0.977)\end{array}$ \\
\hline
\end{tabular}

Note: $\mathrm{p}$-value, $* * *, * *$, and $*$ show significance at $1 \%, 5 \%$, and $10 \%$ level respectively

Source: Authors' estimations.

The spatial models allow for separating the direct and indirect effects of dependent variables. Direct effects measure the effects of independent variables on the dependent variable of a given country, whereas indirect effects measure the effects of independent variables in the neighboring countries on the dependent variable of a given country. Table 7 reports the direct and indirect effects of all variables of Model 1 and the variables of the internal and external conflicts in Models 2-7. A comparison of Tables 6 and 7 suggests that the direct effects are slightly different from the estimates since the direct effects include feedback effects resulting from the effects of crossing neighboring states and returning to the state of origin.

Table 7. Marginal effects of the $\mathrm{CO}_{2}$ determinants

\begin{tabular}{ccc|cc|cc}
\hline & \multicolumn{2}{c|}{ Direct } & \multicolumn{2}{c|}{ Indirect } & \multicolumn{2}{c}{ Total } \\
\hline & Coefficient & p-value & Coefficient & p-value & Coefficient & p-value \\
\hline $\ln G D P P$ & -0.476 & $\left(0.000^{* * *}\right)$ & -0.218 & $(0.031 * *)$ & -0.694 & $\left(0.000^{* * *)}\right.$ \\
$\ln O P E$ & 0.006 & $(0.777)$ & 0.015 & $(0.819)$ & 0.021 & $(0.765)$ \\
$\ln R E N T$ & -0.022 & $(0.017 * *)$ & 0.093 & $\left(0.000^{* * *}\right)$ & 0.071 & $(0.004 * *)$ \\
$\ln U R B$ & 0.282 & $\left(0.009^{* * *}\right)$ & -0.756 & $\left(0.000^{* * *}\right)$ & -0.475 & $(0.02 * *)$ \\
$\ln W A R$ & 0.203 & $\left(0.000^{* * *}\right)$ & -0.486 & $(0.011 * *)$ & -0.283 & $(0.159)$ \\
$\ln C C I$ & 0.037 & $(0.001 * * *)$ & -0.016 & $(0.656)$ & 0.02 & $(0.596)$ \\
$\ln F P I$ & -0.035 & $\left(0.000^{* * *}\right)$ & -0.084 & $(0.001 * * *)$ & -0.119 & $\left(0.000^{* * *}\right)$ \\
$\ln C W I$ & -0.077 & $\left(0.000^{* * *}\right)$ & -0.047 & $(0.183)$ & -0.124 & $\left(0.002^{* * *)}\right.$ \\
$\ln T E I$ & -0.036 & $(0.001 * * *)$ & -0.079 & $(0.001 * * *)$ & -0.115 & $\left(0.000^{* * *)}\right.$ \\
$\ln C D I$ & -0.062 & $(0.007 * * *)$ & -0.036 & $(0.54)$ & -0.098 & $(0.13)$ \\
\hline
\end{tabular}

Note: p-value, $* * *, * *$, and $*$ show significance at $1 \%, 5 \%$, and $10 \%$ level respectively

Source: Authors' estimations.

The present study sought to focus on the indirect effects in Table 7 in order to examine the effects of the independent variables of the neighboring countries on maternal mortality in the origin country. The coefficient of the logarithmic GDP per capita in the neighboring countries is -0.218 , indicating that the economic growth of a neighboring country reduces the maternal mortality rate. Also, the coefficient of trade openness in neighboring countries is insignificant. The effects of urbanization and natural resource rents are significantly negative and positive, respectively. The effects of the conflict variables, including war, foreign pressures, and terrorism in neighboring countries are negative and significant. 


\section{Discussion}

Maternal mortality rates are much higher in poor countries with poor health structures than in other parts of the world. Focusing on the challenges in this regard for a wide range of countries, the present study attempted to provide a framework for future studies to reduce maternal mortality rates. The present study spatially explored the effects of maternal mortality determinants. Data from forty-six African and Middle Eastern countries from 2011 to 2017 were used to highlight the regional impacts of internal and external conflicts on maternal mortality rates. Diagnostic tests emphasize the existence of spatial interactions in relation to model variables; thus, the spatial Durbin model was used to investigate the effects of independent model variables. Based on the results, economic growth provides a basis for reducing maternal mortality. The creation of wider health infrastructures and the expansion of health services in the economy are among the contributions of economic growth to countries. This, in turn, can diminish maternal mortality. Although trade openness can enhance maternal mortality through increased imports of technological healthcare goods, the results revealed that such effects are insignificant in the countries under study. Natural resource rents are a significant variable in reducing mortality rates within the countries under study, in the sense that countries provide the necessary financial resources to cover health expenditures through revenues from the sales of natural resources. The existing realities in relation to the countries under study show the weak production structure of these countries; the tax revenues of these countries in the manufacturing sector are very low, and their health expenditures would encounter serious challenges in the absence of natural resource rents. The expansion of urbanization has also paved the way for the expansion of maternal mortality. Urbanization mainly arises from inequality in development factors, such as household income, access to welfare facilities, and infrastructure. Therefore, infrastructure and facilities in rural areas can help reduce the increasing rate of urbanization and the associated anomalies. It could be adopted as a policy to address inequality. The results of the present study indicated that the implementation of such policies can reduce maternal mortality.

\section{Conclusion}

After examining the effects of model control variables, the effects of internal and external conflicts were evaluated in the form of two different models. The results for some variables are inconsistent with theoretical expectations; for example, war and cross-border conflicts were found to reduce maternal mortality rates. It seems that the health sector is dependent on how internal and external conflicts affect the combination of production and specialized financial resources. The results suggest that war and cross-border conflicts raise the alleviating contribution of economic growth to maternal mortality, implying that health financial resource allocations and health services expand when such conflicts increase, and a greater production orientation in the economy appears toward health services. The results are quite different for other conflict variables, including foreign pressures, civil war, terrorism, and civil disorder. Most of these variables are considered as the components of internal conflicts other than foreign pressures. As a result of the increase in such conflicts in countries, there is a change in the composition of production to the detriment of health services, and the positive effects of economic growth on maternal mortality reduction are diminishing. Overall, most conflict variables increase maternal mortality by reducing health services in the economy. According to the results, conflicts such as war, foreign pressures, and terrorism in neighboring countries have spillover effects on the regional extensions of maternal mortality rates and enhance mortality rates in the country of origin. In addition to widespread internal and external conflicts in African and Middle Eastern countries, other structural and institutional variables may explain the high 
level of maternal mortality in these countries, the study of which requires more extensive research in future works.

\section{Declarations:}

\section{Acknowledgments}

Not applicable.

\section{Authors' contributions}

SR and SK planned the paper and wrote the first draft of the manuscript; MK provided input and estimated the results; all authors reviewed and approved the final version.

\section{Funding}

Not applicable.

\section{Availability of data and materials}

The datasets used and/or analyzed during the current study are available from the corresponding author on reasonable request.

\section{Ethics approval and consent to participate}

Not applicable.

\section{Consent for publication}

Not applicable.

\section{Competing interests}

None declared.

\section{Author details}

1 Assistant Professor of Economics, Faculty of Economics and Social Sciences, Bu-Ali Sina University, Hamedan, Iran. 2 Assistant Professor of Economics, Faculty of Economics and Social Sciences, Bu-Ali Sina University, Hamedan, Iran. 3 M.Sc. in economics. Urmia University.

\section{References}

Abdul Cader, A., \& Perera, L. (2011). Understanding the impact of the economic crisis on child and maternal health among the poor: Opportunities for South Asia (No. 293). ADBI Working Paper. Tokyo: Asian Development Bank Institute. Available: http://www.adbi.org/workingpaper/2011/07/01/4624.

Anselin, L., Le Gallo, J., and Jayet, H. (2008). Spatial panel econometrics. In The econometrics of panel data (pp. 625-660). Springer, Berlin, Heidelberg.

Baltagi, B.H. (2005). Econometric analysis of panel data 3rd Edition England John Wiley and Sons.

Bayati, M., Vahedi, S., Esmaeilzadeh, F., Kavosi, Z., Jamali, Z., Rajabi, A., \& Alimohamadi, Y. (2016). Determinants of maternal mortality in Eastern Mediterranean region: A panel data analysis. Medical journal of the Islamic Republic of Iran, 30, 360. 
Boserup, R.A., et al., eds. (2017), New Conflict Dynamics. Between Regional Autonomy and Intervention in the Middle East and North Africa. Copenhagen, Danish Institute for International Studies, https://www.diis.dk/en/node/7186.

Burridge, P. (1980). On the Cliff-Ord test for spatial correlation. Journal of the Royal Statistical Society: Series B (Methodological), 42(1), 107-108.

Chandrasekhar, S., Gebreselassie, T., \& Jayaraman, A. (2011). Maternal health care seeking behavior in a post-conflict HIPC: the case of Rwanda. Population Research and Policy Review, 30(1), 25-41.

Ensor, T., Cooper, S., Davidson, L., Fitzmaurice, A., \& Graham, W. J. (2010). The impact of economic recession on maternal and infant mortality: lessons from history. BMC public health, 10(1), 727.

Ghobarah, H. A., Huth, P., \& Russett, B. (2003). Civil wars kill and maim people-long after the shooting stops. American Political Science Review, 189-202.

Gizelis, T.-I., \& Cao, X. (2016). Peacekeeping and Post-conflict Maternal Health. Typescript: University of Essex and Penn State University.

Gustafson, P., Gomes, V. F., Vieira, C. S., Jensen, H., Seng, R., Norberg, R., Samb, B., Naucler, A., \& Aaby, P. (2001). Tuberculosis mortality during a civil war in Guinea-Bissau. Jama, 286(5), 599-603.

Hogan, M. C., Foreman, K. J., Naghavi, M., Ahn, S. Y., Wang, M., Makela, S. M., Lopez, A. D., Lozano, R., \& Murray, C. J. (2010). Maternal mortality for 181 countries, 1980-2008: a systematic analysis of progress towards Millennium Development Goal 5. The lancet, 375(9726), 1609-1623.

Iqbal, Z. (2006). Health and human security: The public health impact of violent conflict. International Studies Quarterly, 50(3), 631-649.

Iqbal, Z. (2010). War and the Health of Nations. Stanford University Press.

Iqbal, Z., \& Zorn, C. (2010). Violent conflict and the spread of HIV/AIDS in Africa. The Journal of Politics, 72(1), 149-162.

Kotsadam, A., \& Østby, G. (2019). Armed conflict and maternal mortality: a micro-level analysis of sub-Saharan Africa, 1989-2013. Social Science \& Medicine, 239, 112526.

Kottegoda, S., Samuel, K., \& Emmanuel, S. (2008). Reproductive health concerns in six conflict-affected areas of Sri Lanka. Reproductive Health Matters, 16(31), 75-82.

LeSage, J.P, and Pace, R.K. (2009). Introduction to spatial econometrics. Boca Raton, CRC Press Taylor and Francis Group.

Lindskog, E. E. (2016). The effect of war on infant mortality in the Democratic Republic of Congo. BMC public health, 16(1), 1-10.

Mirzazada, S., Padhani, Z. A., Jabeen, S., Fatima, M., Rizvi, A., Ansari, U., Das, J. K., \& Bhutta, Z. A. (2020). Impact of conflict on maternal and child health service delivery: a country case study of Afghanistan. Conflict and health, 14(1), 1-13.

Mullany, L. C., Lee, C. I., Paw, P., Oo, E. K. S., Maung, C., Kuiper, H., Mansenior, N., Beyrer, C., \& Lee, T. J. (2008). The MOM Project: delivering maternal health services among internally displaced populations in eastern Burma. Reproductive Health Matters, 16(31), 4456.

Namasivayam, A., González, P. A., Delgado, R. C., \& Chi, P. C. (2017). The effect of armed conflict on the utilization of maternal health services in Uganda: a population-based study. PLoS currents, 9.

Nikzadian, A., Agheli, L., Arani, A. A., \& Sadeghi, H. (2019). The Effects of Resource Rent, Human Capital and Government Effectiveness on Government Health Expenditure in Organization of the Petroleum Exporting Countries. International Journal of Energy Economics and Policy, 9(2), 381-389.

Obermeyer, Z., Murray, C. J., \& Gakidou, E. (2008). Fifty years of violent war deaths from 
Vietnam to Bosnia: analysis of data from the world health survey programme. $B m j$, 336(7659), 1482-1486.

O'hare, B. A., \& Southall, D. P. (2007). First do no harm: the impact of recent armed conflict on maternal and child health in Sub-Saharan Africa. Journal of the Royal Society of Medicine, 100(12), 564-570.

Plümper, T., \& Neumayer, E. (2006). The unequal burden of war: The effect of armed conflict on the gender gap in life expectancy. International organization, 723-754.

Plümper, T., \& Neumayer, E. (2006). The Unequal Burden of War: The Effect of Armed Conflict on the Gender Gap in Life Expectancy. International organization, 60(3), 723-754.

Randall, S. (2005). The demographic consequences of conflict, exile and repatriation: A case study of Malian Tuareg. European journal of population/Revue Européenne de Démographie, 21(2-3), 291-320.

Ruiz-Cantero, M. T., Guijarro-Garvi, M., Bean, D. R., Martínez-Riera, J. R., \& Fernández-Sáez, J. (2019). Governance commitment to reduce maternal mortality. A political determinant beyond the wealth of the countries. Health \& place, 57, 313-320.

Swatzyna, R., \& Pillai, V. (2013). The effects of disaster on women's reproductive health in developing countries. Global Journal of Health Science, 5(4), 106-113.

Toole, M. J. (2000). Displaced persons and war. War and public health, New York: Oxford University Press, 197-214.

UN High Commissioner for Refugees (UNHCR). (2017). Overview on UNHCR's operations in the Middle East and North Africa (MENA), 23 September 2016, available at: https://www.refworld.org/docid/57f25a284.html.

Urdal, H., \& Che, C. P. (2013). War and gender inequalities in health: the impact of armed conflict on fertility and maternal mortality. International Interactions, 39(4), 489-510.

Urdal, H., \& Che, C. P. (2013). War and gender inequalities in health: the impact of armed conflict on fertility and maternal mortality. International Interactions, 39(4), 489-510.

Wagner, Z., Heft-Neal, S., Wise, P. H., Black, R. E., Burke, M., Boerma, T., Bhutta, Z. A., \& Bendavid, E. (2019). Women and children living in areas of armed conflict in Africa: a geospatial analysis of mortality and orphanhood. The Lancet Global Health, 7(12), e1622e1631.

Wang, G.-z. (2014). The impact of social and economic indicators on maternal and child health. Social indicators research, 116(3), 935-957.

Welander, A., Lyttkens, C. H., \& Nilsson, T. (2015). Globalization, democracy, and child health in developing countries. Social Science \& Medicine, 136, 52-63.

Wigley, S., \& Akkoyunlu-Wigley, A. (2017). The impact of democracy and media freedom on under-5 mortality, 1961-2011. Social Science \& Medicine, 190, 237-246.

Woldemicael, G. (2008). Recent fertility decline in Eritrea: Is it a conflict-led transition? Demographic Research, 18, 27-58.

Zolala, F., Heidari, F., Afshar, N., \& Haghdoost, A. A. (2012). Exploring maternal mortality in relation to socioeconomic factors in Iran. Singapore medical journal, 53(10), 684. 
Figures

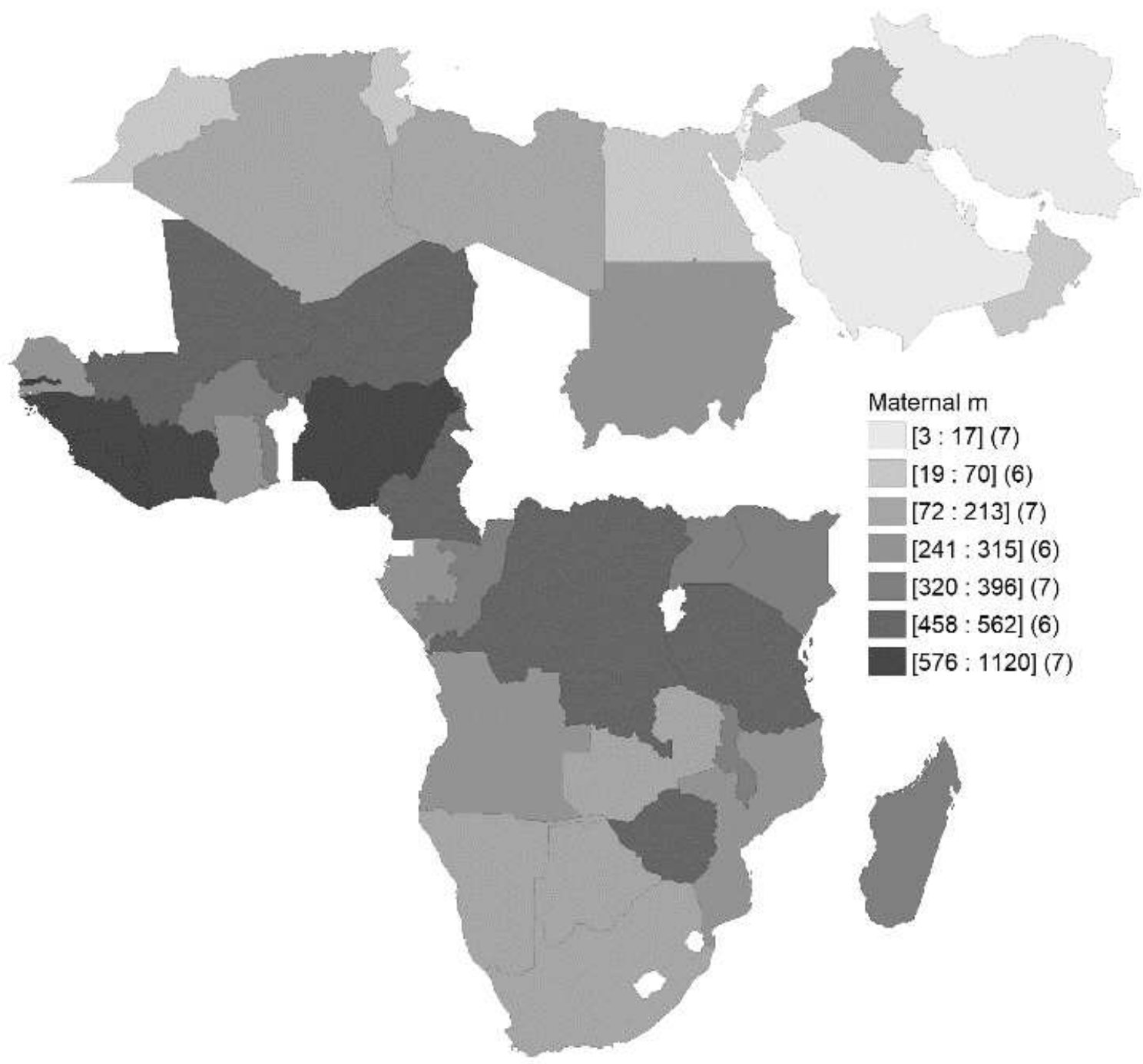

Figure 1

Maternal mortality per capita 


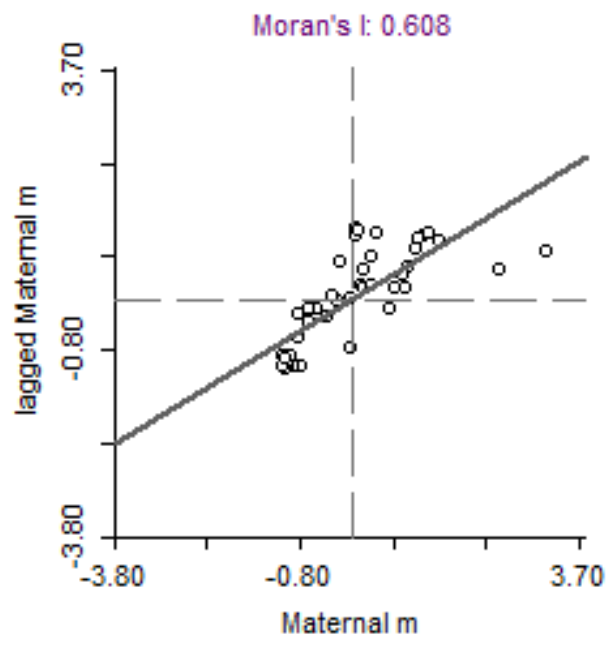

Figure 2

Moran's I statistics across countries 